\title{
Aikuisten mediatajun jäljillä
}

JUHASUORANTA

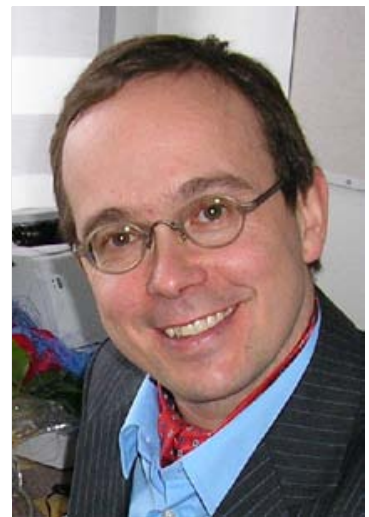

Aikuiskasvatuksessa on tiedostettava ja riitautettava vääristynyt käsitys, jonka mukaan elämän pitäisi vastata televisiota siisteine ja onnellisine loppuineen. - Stephen Brookfield (1996, 893)

Lukutaito ei ole todellista ellei se liity itsen ja maailman ilmaisuun, luomiseen ja uudelleen luomiseen, sekä mahdollisuuteen päättää, valita ja osallistua yhteiskunnan toimintaan. - Paulo Freire (1998, 486)

M Mediakasvatuksen tutkimuksen ja opetuksen painotukset ovat vaihdelleet viime vuosikymmeninä. 1970-luvun tiedostavasta suuntauksesta siirryttiin 1980-luvulla populaarikulttuurin mielihyvän tutkimukseen ja seuraavalla vuosikymmenellä kiinnostuttiin informaatioteknologioiden opetuskäytöstä. Mediakasvatus on sekä Suomessa että muualla liitetty ennen kaikkea lasten kasvattamiseen, harvemmin aikuiskasvatukseen. Vaikka empiiristä tutkimusta aikuisten mediakäytännöistä on olemassa, ei aikuisten mediakasvatusta mainita esimerkiksi aikuiskasvatuksen viimeisimmissä käsikirjoissa (Merriam \& Cunningham 1989; Tuijnman 1996; Wilson \& Hayes 2000) lukuun ottamatta etäopetusta ja opetusteknologiaa sekä lyhyttä mainintaa aikuisten medialukutaidon tärkeydestä (Brookfield 1996, 893). Aikuiskasvatuksen teoriassa ja tutkimuksessa näyttää olevan aikuisten mediakasvatuksen mentävä aukko.

Seuraavassa tarkastelen ensin mediaa aikuisten kasvattajana radikaalin aikuiskasvatuksen perinteen (ks. esim. Thompson 1980; Thomas 1982; Youngman 1986; Lovett 1988; Westwood \& Thomas 1991; Allman 2001; Foley 2001; Holst 2002; Brookfield 2005; Freire 2005; Nesbit 2005; Huttunen \& Suoranta 2006; Newman 2006) näkökulmasta, sitten aikuista median käyttäjänä empiiriseltä kannalta ja lopuksi aikuisten mediakasvatuksen tehtäviä. (viite 1). Itse median käsi- te on huomattavan laaja ja monimerkityksinen; tässä yhteydessä tarkoitan sillä kuvaan, tekstiin ja ääneen perustuvaa välittynyttä viestintää (internetin sisältöjä, mainoksia, lehtijuttuja ja televisio- tai radio-ohjelmia), joka tavalla tai toisella liittyy aikuisten arkeen. Näistä muodostuu visuaaliseksi kulttuuriksi, audiovisuaaliseksi mediakulttuuriksi tai pelkästään mediakulttuuriksi kutsuttu kokonaisuus (ks. Kellner 1998; Herkman 2001; Seppänen 2005).

Olen aiemmin tarkastellut mediakulttuurin merkitystä kasvatukselle kriittisessä pedagogiikassa ja kulttuurintutkimuksessa käytetyn "kulttuurin pedagogiikan" käsitteen avulla. Se viittaa median kasvattavuuteen sekä lasten, nuorten ja aikuisten alttiuteen ennen kaikkea mediavälitteisen populaarikulttuurin vaikutuksille. Lisäksi se korostaa eri median asemaa nykykulttuurin kiinteänä, ehkä muodollista koulutustakin tärkeämpänä osana (Suoranta 2003). Siksi kasvatus nähdään "laajana joukkona sosiaalisia laitoksia, jotka kasvattavat: muodollisen koulutuksen lisäksi kirjastot, museot, päiväkodit, radio ja televisio sekä työpaikat" (Cremin 1975).

\section{Media käyttää aikuisia...}

Kun mediasta, teksteineen ja kuvineen, tuli 1900luvulla maailmankuvien, aatteiden, datan, viihteen ja mainosten välittäjänä uudenlainen kas- 
vatusvoima, on siitä tullut luonnollinen lähtökohta myös mediakasvatukselle, viime aikoina jopa lasten medialta suojelulle. (viite 2). Lisäksi on käynyt selväksi, ettei mediakasvatus voi koskea vain lapsia ja nuoria, vaan se on ulotettava myös aikuisiin. Radikaalin aikuiskasvatuksen näkökulmasta media on yleensä nähty tärkeäksi informaaliksi kasvattajaksi ja oppimisen välineeksi, mutta epädemokraattisissa oloissa ja omistuksen keskittymisen seurauksena myös uhkaksi yhteiskuntien monimuotoisuudelle ja demokratialle (Guy 2006). Näiden kysymysten pohdinta vaatii kehittynyttä "mediatajua" (Sihvonen 2004).

Radikaalin aikuiskasvatuksen teoriassa on erityisesti tuotu esille joukkotiedotuksen suhde talouteen, politiikkaan ja kulttuurin, sekä pohdittu laajemminkin eri median kytkeytymistä inmisten arkeen. Media nähdään osana yhteiskunnan rakentumista, jolloin esimerkiksi median omistussuhteiden yhteydet mediasisältöihin tulevat kiinnostuksen kohteeksi (ks. Herkman 2005). Samoin mediaa lähestytään ideologisena muotona, eli ollaan kiinnostuneita median poliittisesta merkityksestä ja niistä tavoista, joilla se ohjaa esimerkiksi inmisten terveys-, kulutus- ja äänestyskäyttäytymistä niin asiasisällöin kuin mainoksinkin.

Radikaalissa aikuiskasvatuksessa käytetään ja tulkitaan muiden kriittisten aikalaisajattelijoiden ohella Karl Marxia, joka väitti poliittisen taloustieteen kritiikissään, että kapitalismi taloudellisena suhteena ja sosiaalisena elämänmuotona esineistää ihmisten hienovaraisimmatkin suhteet. Vuonna 1848 Marx kirjoitti yhdessä Friedrich Engelsin kanssa laatimassaan Kommunistisessa manifestissa: "Sivistys jonka menettämistä porvari valittaa, on tavattoman suurelle enemmistölle muuttumista koneeksi" (Marx \& Engels 2006). He ennakoivat, että teollisen kapitalismin yhteiskunnalliset suhteet tulevat kurjistamaan elämän ja kasvatuksen: "Porvarilliset lauseparret perheestä ja kasvatuksesta, vanhempien ja lasten hellästä suhteesta käyvät sitä tympäisevämmiksi, mitä enemmän kaikki proletaarien perhesiteet suurteollisuuden kehittymisen seurauksena revitään rikki ja lapsista tehdään pelkkiä kauppaesineitä ja työkaluja" (emt.).

Tätä kirjoittaessani keväällä 2006 levisi ylikansallisilla televisiokanavilla uutinen internetin lapsipornon yleisyydestä - eräästä lasten esineellistämisen nykyaikaisesta, julmasta ja tuomittavasta muodosta. Vaikka esineellistämisen muodot muuttuvat, näyttää kaiken taustalla silti periaatteessa toimivan sama yhteiskunnan rakentumisen logiikka kuin vuosisata aiemminkin. Uudet ilmiöt ovat huolestuttavia kuten sekin, ettemme välttämättä aina tiedosta niiden taustalla olevia selittäviä tekijöitä, kuten kapitalismin rakenteellista logiikkaa, ja hukkaamme siten mahdollisuuden ilmiöiden syvään analyysiin. Valtamediassa ilmiön kanssa panikoitiin etsimällä syyllisiä ja tuottamalla studioihin pika-ajattelijoita, joiden iskulause oli: "esineistämme lapset ja menetämme heidät ihmishirviöille". Argumentti edusti kotikutoista "psyko-marxismia", jossa Marxilta oli omaksuttu esineistymisen käsite ja loput lisätty psykologiasta. Ääri-ilmiöiden yhteydessä tällaiset kommentit eivät edistä yhteiskunnan tilan tiedostamista, joka johtaisi myös kestäviin kasvatuksellisiin päätelmiin.

Slovenialaisfilosofi Slavoj Žižek (2006a) kirjoittaa pariisilaiskollegaansa Étienne Balibariin viitaten kahdesta informaatiokapitalismille, eli informaatio- ja pääomavirtojen nopeaan liikkeeseen perustuvalle maailmanjärjestykselle tyypillisistä väkivallan muodoista. Yhtäällä on rakenteellinen väkivalta, nykypäivän valtavat taloudelliset ja yhteiskunnalliset erot, voittajat ja häviäjät; toisaalla on subjektiivinen väkivalta, kuten rasismi, uskonnollinen fanatismi, sekä monenlaiset arkielämän psykologiset ja sosiaaliset patologiat, kuten riippuvuudet, syömishäiriöt, videopelaaminen, perversiot ja pedofilia. Valtamedia, jolla lähinnä tarkoitetaan vakiintuneita uutislähteitä (kuten vasemmistoakin äänestävien keskuudessa luetuimpia, yleensä porvarillisia sanomalehtiä ja tv-kanavia), läpäisee molemmat väkivallan lajit. Rakenteellista väkivaltaa valtamedia käyttää tekemällä esimerkiksi toimituksellisia ratkaisuja, joiden puitteissa mielipiteitä muodostetaan ja maailmankuvia luodaan. Subjektiivinen väkivalta näkyy taas esimerkiksi siinä, että kaikkea on tarjolla ylen määrin ja liikaa uutisista huoleen, mainoksista pornoon - yhdessä sekavassa vyyhdessä, josta ei ota selvää.

Median toiminnalle ja ilmiölle on toisin sanoen olemassa ensisijaisia syitä ja toissijaisia syitä. Kriittiset teoreetikot asettavat ensisijaiseksi vaikuttajaksi kapitalismin rakenteellisen logiikan, josta monet edellä luetellun kaltaiset ongelmat sitten seuraavat. Kuka silloin esimerkiksi lapsipornoa käsitelleen uutisen yhteydessä on hirviö, kuka uhri, kuka syyllinen: pornokuvia lataava aikuinen vai uutisesta huolestuva vanhem- 
pi, jonka ymmärrys ulottuu ehkä vain tuomitsemaan; tai ehkä molemmat? Asiaa on hyödytön ryhtyä ratkaisemaan pelkästään moralisoiden. IImiöt on nähtävä kaikilla tasoillaan. Tuomitsemisen ohella on päästävä ilmiöiden pintaa syvemmälle, aina niiden yhteiskunnallisiin juuriin saakka.

Esimerkiksi juuriin menemisestä sopii kriittinen teoreetikko Herbert Marcuse (1898-1979), joka jo 1960-luvun lopulla pyrki paljastamaan teollisten länsimaiden piiloisen aggressiivisuuden, yksiulotteisuuden ja arvaamatta ilmenevän väkivallan. Eräänä tällaisen väkivallan lähteenä Marcuse näki median, erityisesti radion ja television, ja niiden keskeisenä piirteenä toiston ja hämäyksen - samojen sananparsien, aiheiden ja ohjelmien toistumisen uudelleen ja uudelleen. Marcuse viittasi analyysissaan muun muassa Freudin esille nostamaan toistopakkoon, joka riittävän kauan jatkuessaan johtaa muistin ja ajattelukyvyn menetykseen sekä psyykkiseen romahdukseen. Hän muistutti myös Hitleristä, joka tunsi toiston tuhovoiman itsenäiselle ajattelulle. "Jopa lievemmissä muodoissaan jatkuva toisto voi olla destruktiivista tuhoten henkisen itsenäisyyden, ajattelun vapauden ja vastuuntunnon, ja edistäen inertiaa, alistumista ja muutoshaluttomuutta" (Marcuse 2006). Vastaavasti hämäämistä käytetään asiantuntevasti hyväksi yhteiskuntaelämän eri lohkoilla politiikasta propagandaan ja mainontaan: "Taikuus, noituus ja hurmoksellisuus ovat osa kotien ja kauppojen ja toimistojen jokapäiväistä elämänmenoa; ja järkiperäinen suorituskyky estää näkemästä kokonaisuuden järjettömyyttä" (Marcuse 1969, 199).

Marcuse huomautti myös hieman ironisesti siitä, että toistolle perustuva yhteiskunta, eräänlainen sähkösikiöiksi muuttuneiden ihmisten "kansalaiskohtu", on omiaan vähentämään älyllisestä pohdinnasta aiheutuvaa stressiä ja painetta itsenäiseen ajatteluun. - Mainittakoon, että samansuuntaista massa- ja viihdeyhteiskunnan kritiikkiä esitti samoihin aikoihin suomalaisessa aikuiskasvatuksen filosofiassa Urpo Harva, joka näyttää tunteneen Marcusen ajattelua (ks. Harva 1957), mutta edustaneen paljolti kriittisestä teoriasta ja radikaalista aikuiskasvatuksesta poikkeavia lähtökohtia (ks. esim. Harva 1964). Toisin kuin radikaalissa aikuiskasvatuksessa, jossa korostetaan yhteistoimintaan perustuvaa oppimista ja ruohonjuuritason paikallista toimintaa sekä yhteisökasvatusta ja yhteisen kulttuurin luomis- ta "alhaalta ylös", Harva piti "massojen" sivistämistä ja kasvatusta ennen kaikkea eliitin tehtävänä. Hän suhtautui varauksellisesti sivistyksellisen demokratian ja koulutuksellisen tasa-arvon tavoitteisiin pitäen niitä utopistisina ja virheellisinä, myöhemmin tosin joitain myönnytyksiä tehden (ks. Harva 1980, 31-32). (viite 3).

Muutettavat muuttaen Marcusen analyysi pätee nykymaailmassakin erottuen siitä usein tutkijoidenkin suulla julkisuudessa esitetystä kommentoinnista, jossa paheksutaan milloin internetin lieveilmiöitä milloin vaikkapa tosi-tv:n nöyryytyskulttuuria. Näissä näennäisen huolestuneissa kommenteissa ilmiötä ei juuri kytketä kapitalismin kulttuuristumiseen, eli kulttuurin kaupallistumiseen ja tavaraistumiseen, eikä niissä ylletä näkemään ihmisen esineellistämisen ja nöyryytyksen yhteiskunnallisia yhteyksiä. Tässä tilanteessa tiukka moralismikin saattaa näyttää houkuttelevalta, mutta kunnon ratkaisuksi siitä ei ole. Aikuiskasvatuksen kannalta olennaisempi kysymys on, miten informaatiokapitalismissa kehitetään yhteiskunnallista tietoisuutta?

\section{... mutta käyttävätkö aikuiset mediaa?}

Toisaalta Marcusen edustamassa kriittisessä teoriassa esitetään vain harvoin suoria toimenpideohjelmia asioiden korjaamiseksi ja kriittisen tietoisuuden kehittämiseksi. Siinä ei liioin luoteta yksilöiden kykyyn muuttaa yhteiskuntaa, ainakaan yksinään. Tämä johtuu kriittisen teorian lähtökohdista, joista on puuttunut käsitys sekä yhteiskunnallisesta toimijasta eli agentista että median ja populaarikulttuurin kasvatuksellisuudesta. Analyysi on yleensä suunnattu mediavaltaan, eli kysymykseen yhteiskunnan hallinnasta ja tämän sosiopsykologisista vaikutuksista inmiselle ja yhteiskunnalle. On uskottu kritiikin esittämiseen keinona aikuisten kasvattamiseen, heidän silmiensä avaamiseen. Tähän kritiikkiin on piiloutunut myös ilmiselvää elitismiä, tavallisten inmisten järjen ja omatoimisuuden epäilyä.

On kuitenkin empiiristä näyttöä siitä, että aikuiset puntaroivat mediaa myös kriittisesti (ks. Moores 2000; Silverstone 2005; Suoranta \& Lehtimäki 2004). Siksi median aikuiskasvatustieteellisessä tutkimuksessa tarvitaan kulttuurintutkimuksen "aktiivisen katsojan" ja toimijan käsitteitä, ja tietenkin lisää empiiristä tutkimusta. Aktiivisen toimijan teoriassa ajatellaan, että tietyt historiallis-sosiaaliset tekijät, kuten yhteiskun- 
taluokka, sukupuoli ja etnisyys, antavat lähtökohdan ihmisten toiminnalle ja ajattelulle, mutta eivät heitä määrää. Lähes kaikissa olosuhteissa ihmiset voivat myös toimia toisin: ryhtyä kriittisiksi, kehittää omaa mediatajuaan. Jotain vihiä aikuisten jokapäiväisestä mediatajusta tarjoaa päiväkirja-aineisto, jossa eri-ikäiset suomalaiset kuvaavat elämäänsämediassayhden päivänajan. Aineiston ovat vuonna 2001 koonneet Yleisradion Yleisötutkimus ja Jyväskylän yliopiston nykykulttuurin tutkimusyksikkö (viite 4).

Päiväkirja-aineiston voi ainakin alustavan luennan perusteella jakaa karkeasti kolmeen luokkaan: niihin, joissa elämä mediassa kuvataan kaikin puolin aktiiviseksi, passiiviseksi tai jollain tavalla (esimerkiksi jonkin tietyn median seuraamiseen) painottuneeksi. Tähän yhteyteen olen valinnut noin kolmekymmenvuotiaan naisen kirjoittaman päiväkirjan, jota pidän tyypillisenä esimerkkinä (tyypittelystä ks. Eskola \& Suoranta 1998, 182) aktiivisen mediaelämän kuvauksesta. Päiväkirja alkaa kirjoittamishetkellä ajankohtaisen aiheen puinnilla:

"Nils Torvalds on tehnyt ansiokkaan raportin Morgonnyttiin yhdysvaltalaista energiayhtiö Enronia uhkaavasta konkurssista, kun taas YLEn aamulähetyksen suomenkielisissä uutisissa ei kerrota mitään taustoista (...) vaan ainoastaan yhtiön taloudellisesta nykytilanteesta ja sijoittajien reaktioista eli raivostuttava 'pörssinäkökulma' näissä uutisissa. MTV3 ei tainnut ottaa aihetta edes käsittelyyn." (0002N196316)

Lisäksi päiväkirjassa kuvataan median sovittautumista kirjoittajansa jokapäiväiseen elämään: mies on illalla nukahtanut sohvalle television ääreen, ja hänet on hätistettävä siitä aamulla sänkyyn jatkamaan uniaan. Ei ole löytynyt tyydyttävää järjestelyä, jossa kirjoittaja, hänen miehensä ja televisio voisivat "mukavasti olla samaan aikaan samassa huoneessa". Suomalaisilta kanavilta kertoja siirtyy vilkaisemaan Ruotsin kanavat, mutta niissä ei ole uutta.

Aamutouhujen jälkeen hän avaa tietokoneen aloittaakseen päivän työt. Hän tarkistaa uutisotsikot ja sähköpostin. Sitten soittaakin äiti kysyäkseen apua kännykän hankinnassa. Äiti kysyy myös, säilyttääkö tyttärelleen paikallislehdet vai heittääkö ne menemään? Niitä on jo yli viikon ajalta, joten antaa mennä keräykseen.
Netistä ja sähköpostilistoilta ei näytä löytyvän mitään merkittävää, jonka voisi laittaa kirjoittajan pitämälle ekologista asiaa sisältävälle nettisivustolle. Lounasaikaan hän huomaa television olevan edelleen päällä, mutta äänettömällä. Tiskatessa on mukava kuunnella äänikirjaa. Iltapäivällä televisiosta tulevat katsomisen anvoisten asiaohjelmien uusinnat.

Iltasella ruotsalainen kanava esittää painavaa asiaa maahanmuuttajien asemasta. Kirjoittaja toivoo, että myös Suomessa jaksettaisiin tehdä "tällaista tutkivaa journalismia, jossa kaivetaan esille yhteiskunnallisia epäkohtia". Illalla, miehen nukkuessa television ääressä, hän lukee sängyssä ajanvietekirjallisuutta.

Tämän kaltaista aktiivista elämää mediassa luonnehtii yleisemmin ainakin kolme piirrettä, joihin esimerkkitapauskin osaltaan viittaa. Se on ensinnäkin luonteeltaan "opinnollista" toisin kuin passiivisen mediaelämän "viihteellisyys"; mediaa käytetään tietoperäisiin päämääriin, joko työhön tai muuhun elämään liittäen. Toiseksi käytetään aktiivisesti monia medioita, vastakohtana jonkin tietyn median käytölle tai seuraamiselle. Esimerkkipäiväkirjan kirjoittajan päivään mahtuu useita televisionkanavia, sanomalehtiä, kirjoja ja äänikirjoja sekä tietokone interneteineen, sähköposteineen ja keskustelupalstoineen. Selviää, että kirjoittaja seuraa myös sanomalehtiä. Kolmanneksi aktiivinen elämä mediassa on median sisältöjä ja muotoja arvioivaa toisin kuin passiivisessa median käytössä. Kun katsellaan televisiota, on katselun laatu pikemminkin pohtivaa, valikoivaa ja arvioivaa kuin tapaan perustuvaa "tuijotusta".

Empiirisen aineiston päiväkirjoissa kuvataan lukuisin tavoin, miten media sovittautuu osaksi päivän kulkua ja yhteyksien pitoa, ja miten sen sisällöstä keskustellaan. Median seurannassa on eroja toisaalta iän suhteen: vanhempaa väkeä kiinnostavat lehdet ja televisio, nuorempi polvi on ottanut käyttöönsä internetin ja mobiililaitteet, vaikka ero näiden välillä lienee tasoittumassa. Eri median muodot ovat eräänlaisia keskustelukumppaneita, joita kommentoidaan ja arvioidaan, ja joista puhutaan. Tai, kuten television katselua pitkittäisesti päiväkirjojen avulla Iso-Britanniassa tutkineet David Gauntlett ja Annette Hill (2000, 110-139) huomauttavat, televisio on seuralainen, joka antaa jutun juurta mutta aiheuttaa myös syyllisyyttä "ajanhaaskuuna". Syyllisyys liittyy television katseluun aamulla tai päivällä, 
kun pitäisi tehdä muuta, tai koettuun huonoon makuun. Jotkut syyllistivät itseään myös siitä, että pakottivat muut katselemaan omaa mieliohjelmaansa. Lisäksi syyllisyys liitettiin hyvää ja huonoa ajankäyttöä koskeviin arvostuksiin, kuten 75-vuotias mies, entinen koulutarkastaja, kirjoittaa:

"Tunnen toisinaan syyllisyyttä television katselemisesta, etenkin jos olen katsellut sitä jonain päivänä yli kolme tuntia. Syyllisyys johtuu siitä, että katsellessa on jotenkin passiivisessa tilassa ja olisi niin paljon muuta palkitsevampaa tekemistä (kuten lukeminen, kirjoittaminen, käveleminen jne.). Eniten syyllisyyttä tunnen saippuaoopperoiden ja muiden joutavanpäiväisten ohjelmien katselemisesta." (Emt., 122.)

Aktiivista median käyttöä on syytä tähdentää, koska sen tarkastelu on usein kriittisestäkin mediatutkimuksesta puuttunut. Julkinen keskustelu mediasta näyttää puolestaan usein olevan moralistista ja saavan ajoittain jopa mediapaniikin piirteitä. Molemmat seikat ovat olleet omiaan peittämään näkyvistä empiiristen tutkimusten tuloksen: median ja sen monimuotoisen käytön jokapäiväisyyden (ks. Gauntlett \& Hill 1999; Moores 2000; Silverstone 1999; Volkmer 2006), minkä otteet suomalaisesta päiväkirja-aineistostakin vahvistavat.

Puhutteleva aikuisten mediatajun kannalta on myös viestinnäntutkijoiden havainto niistä tavoista, joilla kansalaiset esitetään britti- ja amerikkalaismediassa mielipidetiedustelujen vastaajina, näistä tehtyjen asiantuntijapäätelmien, tai nopeiden 'katugallupin' ("vox pops") kohteina, tai mielenosoitusten, protestien tai muun aktivismin kollektiivisina toimijoina, tai yksilöinä kertomassa mitä "tavallinen kansa todella ajattelee" (Lewis ym. 2004, 156). Lukiessani suomalaisia päiväkirjoja kohtasin kuitenkin melko toisenlaisen toimijan: mediaa monipuolisesti käyttävän ja sitä pohtivan. Lisäksi päiväkirjat panivat miettimään jokapäiväisen elämän olemusta, ja hakemaan vastausta aikuisuuden ja aikuiskasvatuksen peruskysymykseen: mitä on elää, mitä olla olemassa (viite 5)?

Kaikkiaan aineiston tapauskohtaisen ja kohdittaisen lukemisen perusteella voi olettaa, että aikuiset ovat melko analyyttisia ja kykenevät yllättävänkin hyvin arvioimaan ohjelmien ja jut- tujen laatua. Toisaalta, onko tämä mikään inme, ovathan ihmiset ehtineet aikuisikään elää mediassa runsain mitoin? Toisaalta tämä voi kertoa myös aineistosta ja sen vinoutuneisuudesta, eli päiväkirjan pitäminen ja sen lähettäminen tutkimustarkoituksiin on saattanut innostaa ennen kaikkea niitä, joita media kiinnostaa, paitsi käytön tai kulutuksen kannalta, myös aikalaisilmiönä.

Näillä varauksilla aikuisten kirjoittamat päiväkirjat sisältävät melko runsaasti analyyttista ja osin kriittistäkin suhtautumista median sisältöihin, muotoihin ja toimintatapoihin. Tätä arjen "piiloista" medialukutaitoa on hyödynnetty aikuisten lukutaitoprojekteissa tutkimalla osallistujien kanssa kielen käyttöä ja lukutaitoa jokapäiväisessä elämässä, ja kannustamalla kriittiseen kielitietoisuuteen (critical language awareness) (Tett 2005, 27-35).

\section{Aikuisten mediatajun vankentaminen aikuiskasvatuksen tehtävänä}

Radikaalin aikuiskasvatuksen kannalta ongelma on inmisten todellisten vaikutusmahdollisuuksien ja jokapäiväisen mediatajun kehittämismahdollisuuksien vähäisyys valtamediassa. Vaihtoehtona on pidetty esimerkiksi kansalaisviestinnäksi kutsuttua toimintaa, jossa on löydetty myös internetin mahdollisuudet (ks. Heinonen ym. 2000; Sirkkunen \& Kotilainen 2004). Internet sisältääkin runsaasti tavallisten ihmisten viestintää blogeina, podcasteina ja videocasteina. Suunnitelmallisen aikuiskasvatuksen parissa näitä spontaaneita mediakäytäntöjä olisi mahdollista syventää yhteisin pohdinnoin ja 'mediapiirein'. Tässä on tilaus vapaalle sivistystyölle, jossa voitaisiin harjoitella muitakin mediataitoja kuin internetin käyttöä, esimerkiksi juuri kansalaisviestintää sekä kriittistä medialukutaitoa ja omaehtoista tuotantoa uusilla välineillä.

Vaikka mediakulttuurin analyysi ei ole helppoa, kuten ei muukaan kriittinen reflektio, sen edistämisessä voidaan tukeutua esimerkiksi brasilialaisen kasvatusfilosofi Paulo Freiren ajatuksiin kriittisestä lukutaidosta. Hän on kuvannut itseään "television ja radion ihmiseksi":

"Katselen esimerkiksi saippuaoopperoita ja opin kritisoimalla niitä. Minusta se on huvittavaa. Television katselijana vaadin itseltäni paljon ja siksi se on rasittavaa, en anna hel- 
polla periksi. Tappelen ohjelmia vastaan, jos ymmärrät mitä tarkoitan. Mainokset saavat minut erittäin harvoin pauloihinsa, sillä analysoin niitä, ja löydän niistä lähes välittömästi yhteiskuntaluokkaan, sukupuoleen ja rotuun liittyviä kysymyksiä."(ks. Gadotti 1994, 78).

Jo varhain Freire kiinnitti huomiota erilaisiin lukutaitoihin, siihen miten ja mistä asioita omaksutaan (esim. Freire 1973). Toisaalla ovat hänen mukaansa ne taidot ja tavat, joissa lukeminen ja asioiden omaksuminen on melkeinpä mekaanista. Todellisuus tulee tulkituksi kyselemättä, sellaisena kuin se jonkin ideologisen muodon omaavassa mediassa esitetään. Toisaalla ovat kriittiset lukutaidot ja lukemisen tavat, joissa ilmiöt problematisoidaan. Kriittisessä lukutaidossa painetun sanan lukeminen johtaa paitsi ymmärtämiseen myös maailmaa muuttavaan toimintaan: vääryyksien tiedostamiseen ja niiden korjaamiseen. (Ks. Freire 1998; Freire \& Macedo 1987, 156-159; Suoranta 2005.) Freire ei myöskään väheksynyt informaatioteknologioiden asemaa opetuksessa ja oppimisessa, mutta korosti, että aina on tarpeellista tietää, keitä ja mitä uudet opetusteknologiat palvelevat. Hänelle median käyttö koulutuksessa kiteytyi kysymykseksi yhteiskuntaluokasta; hän pelkäsi informaatioteknologioiden palvelevan pääosin hyväosaisia (Gadotti 1994, 79).

Kenties näkyvimmin medialukutaitoa on aikuiskasvatuksen piiriin ajanut teoreetikko Stephen Brookfield pitämällä mediakasvatusta aikuiskasvatuksen tärkeimpiin kuuluvana tutkimusaiheena ja opetussisältönä. Erityisesti hän on kantanut huolta alan toimijoiden omasta kriittisestä medialukutaidosta yhä useammin tietoverkoissa myytävän aikuiskoulutuksen markkinoilla (Brookfield 1996, 893; Brookfield 2005). Suomessa aikuisten yliopistollisen mediakasvatuksen ja alan tutkimuksen avaukset ovat vasta alussa (viite 6).

Median kasvattavuutta ja aikuisten median käyttöä koskevia tutkimus- ja opiskelukysymyksiä ovat esimerkiksi: mitä asenteita ja toimintamalleja aikuiset oppivat mediasta, tai miten lukea mediaa toisin silmin? Žižek (2006b) nimittää "oikosulkuistamiseksi" (short-circuiting) kriittistä lukutapaansa, jossa jokin ilmiö tai lausuma tulkitaan uudessa ja oudossa valossa. Hänen esimerkkinsä ovat Marx, joka tarkasteli filosofiaa ja uskontoa poliittisen taloustieteen näkö- kulmasta, ja Freud, joka närkästystä herättäen peilasi tabuja ja eettisiä periaatteita tiedostamattoman peilistä. Miksei "oikosulku" kelpaisi kielikuvaksi myös silloin, kun esimerkiksi opintopiireissä etsitään tapoja saada aikuiset pohtimaan median merkityksiä ilman etukäteisoletuksia syyllisistä tai asioiden 'oikeista' järjestyksistä.

Vastausta vaativa kysymys ei ole kriittisen ajattelun kannalta niinkään se, miksi aikuiset oppivat mediasta, vaan se, mitä he oppivat, ja ketä oppiminen palvelee. Brookfieldin kriittisen tulkinnan mukaan nykyinen poliittinen ja taloudellinen systeemi, sekä sen oppilauseita hanakasti toisteleva valtamedia, estävät aikuisten kyselevää ja pohdiskelevaa oppimista. "Koska oppiminen edellyttää miksi -kysymyksiä, se voi olla vaarallista systeemille, ja siksi sitä on kontrolloitava" (Brookfield 2005, 248). Tällaiset kontrolliyritykset eivät, ajoittaisesta menestyksestä huolimatta, kuitenkaan koskaan täydellisesti onnistu.

Informaatiokapitalismissa ja mediatarjonnan virrassa on kuitenkin mahdollista elää myös silmät avoimina: huomioimalla median omistussuhteiden lisäksi kulttuuriseen ylärakenteeseen kuuluvat vaikutusmekanismit ajattelun ja toiminnan muokkaajina. Nämä vaikuttamisen tavat tiedostamalla voi mediaa käyttää myös pohtivan asenteen sekä kriittisen ajattelun ja toiminnan välineenä. Tästä manipulaation ja mahdollisuuksien dialektiikasta nousevan kriittisen mediatajun opiskelun ja kehittämisen haluaisin sisällyttää aikuiskasvattajan tehtäviin.

Kriittistä mediatajua voi aikuiskasvatuksessa edistää muun muassa tutkimalla erilaisten populaarikulttuuristen esitysten ja mainosten luomia hegemonisia, eli vallitsevia ja syrjäytettyjä tai unohdettuja merkityksiä (ks. Lehtimäki \& Suoranta 2006). Tai on mahdollista katsella uutisia, ja miettiä miksi juuri tästä asiasta muttei tuosta tehtiin uutinen. (viite 7). Samoin propaganda, poliittinen populismi ja "kansankiihotus" sekä muunlainen todellisuuden audio-visuaalinen ylidramatisointi ovat analyysin arvoisia teemoja. Aikuisten mediakasvatukseen kuuluu myös vanhempien kasvatus eli kasvatustietoisuuden lisääminen mediakulttuurista. Vanhemmathan joutuvat pohtimaan esimerkiksi television katselun ja kännykän käytön rajoja (ks. Suoranta \& Lehtimäki 2004, 33-37, 44-51). Ja lisäksi heidän tulisi olla tietoisia pelien ikärajoista ja sisällöistä, "nettietiketistä" eli internetin käyttäytymissään- 
nöistä ja pystyä pohtimaan lastensa kanssa mainosten ja tuotemerkkien houkutuksia - ja ylipäätään sitä, mikä on tarpeellista ja mikä ei.

Tärkeää on myös uusien informaatioteknologioiden kokeileminen niiden käyttökelpoisuutta arvioiden ja omaehtoista mediakulttuuria kehitellen. Omassa radikaalissa aikuiskasvatuksessani uskon tiedon ja oppimisen olevan yhdessä toimimista, kokeilemista, luomista ja kyseenalaistamista pikemminkin kuin keräämistä, arvioimista ja omistamista mitattavina pätevyyksinä (ks. myös Tett 2005, 35). Siksi olen ollut viime aikoina innostunut myös wikipediasta (fi.wikipedia.org) yhtenä niin kutsutun "sosiaalisen median" muotona. Sosiaalista mediaa kuvaavampaa olisi tosin puhua vaikkapa "vertaismediasta" (P2P, eli peer-to-peer) tai "osallisuusmediasta", sillä kysymys ei ole pelkästä vastavuoroisuudesta tai "lahjasta", johon "sosiaalinen" näyttäisi viittaavan, vaan siitä, mistä Michel Bauwens (2005) kirjoittaa Marxia mukaillen, osallisuusmediassa "jokainen antaa kykyjensä ja tahtonsa mukaan, ja ottaa tarpeidensa mukaan". Vertaisohjelmien merkitystä ei aikuiskasvatuksessakaan voi ohittaa, vaan pohtia niiden mahdollisuuksia tiedon demokratisoinnille ja vapauttavalle oppimiselle. Ne voivat opettaa tiedon uudenlaiseen avoimuuteen ja oppimisen vieraanvaraisuuteen.

Brookfieldin (1996, 893) sanoin: "Näennäisen demokraattisissa yhteiskunnissa aikuiskasvattajan on pohdittava keinoja, joilla taistella sitä käsitystä vastaan, jonka mukaan median kuvat ja sanat ovat jotenkin objektiivisia, kontekstista riippumattomien viestien kuljettajia". Aikuisten tukeminen media-analyysiin ja mediatajun kehittämiseen on heidän kannustamistaan poliittiseen osallistumiseen ja itsenäiseen ajatteluun sekä maailman muuttamiseen ja vastarintaan - kaikki radikaalin aikuiskasvatuksen tärkeitä tehtäviä.

\section{Viitteet}

(1) Radikaalin aikuiskasvatuksen juuret ovat 1700-luvun valistuksen aateperinnössä, muun muassa anarkismissa, marxismissa ja nationalismissa (Elias \& Merriam 2005, 148-152; ks. myös Boughton 1997). Suuntaukset kehittyivät ensin Euroopassa ja Pohjois-Amerikassa, ja myöhemmin Latinalaisessa Amerikassa ja Afrikassa liittyen alusta asti sivistykselliseen ja poliittiseen toimintaan sekä yhteiskunnallisiin liikkeisiin (Holst 2002, 4-8). Radikaalin kasvatuksen tavoitteena on ollut ja on yhä kapitalistisen ideologian, hegemonian ja vallan kritiikki sekä vapautuminen vieraantuneista olosuhteista kohti yksilöllistä ja sosiaalista vapautta sekä oikeudenmukaista ja demokraattista yhteiskuntaa (Brookfield 2005). Yksilöiden kannalta tärkeänä on pidetty ihmisten auttamista "tulemaan tietoisiksi todellisuudesta, ymmärtämään sen monimuotoisuus ja kehittämään moraalia ilmeisen moraalittomassa maailmassa" (Newman 2006, 10). Lisäksi se on "'minkä tahansa informaation kriittistä analyysia"' (Foley 2005, 39).

(2) Esimerkki viime aikaisesta lasten suojelusta median haitoilta ovat internetin suodattimet ja esto-ohjelmat. Käytännössä ne ovat kehittymättömiä, ja niiden käyttö on joidenkin mielestä rajoittanut sananvapautta. Eräiden näkemysten mukaan suodattimilla ja esto-ohjelmilla on oma rajoitettu paikkansa taistelussa esimerkiksi yhteiskunnan pornoistumista vastaan, mutta kuten kirjastoasiantuntija Tuula Haavisto (HS 12.4.2006) sanoo: "Niillä ratkaistaan vain kolmasosa pulmasta. Loput kaksi osaa ovat mediakasvatus ja mediakasvatus".

(3) Harvan "myönnytys" sivistykselliselle demokratialle liittyi ehkä yllättävästi informaatioteknologioiden kehitykseen. Hän piti kyllä edelleen kiinni "matalatasoisen" kansankulttuurin ja "korkeatasoisen" korkeakulttuurin erosta, mutta kuunnellessaan erään kerran suvisella saarellaan radiosta Kuhmon kamarimusiikkijuhlia, hän sai "ratkaisevan oivalluksen", joka pakotti tarkistamaan näkemystä. Tulevaisuudessa nimenomaan tekniikan kehitys loisi edellytyksiä korkeakulttuurin leviämiselle mahdollistaen paitsi korkeatasoisten musiikin levittämisen ja irrottamisen ajasta ja paikasta myös muun todellisen sivistyksen. "Pian on mahdollista lukea kuhmolaisen tuvan hiljaisuudessa Platonin Valtiota kreikaksi mikrofilmiltä", kirjoitti Harva (1980, 32). Antiikin filosofian lukeminen on tietenkin mahdollista, jos Platon kiinnostaa ja lukija taitaa kreikkaa - molemmat seikkoja, jotka yleensä riippuvat koulutustason lisäksi kulttuurisesta pääomasta, ja joiden kerääminen on sidoksissa sivistykselliseen demokratiaan ja koulutukselliseen tasa-arvoon niin Kuhmossa kuin muualla.

(4) Eri-ikäiset suomalaiset kirjoittivat päiväkirjojaan ( $\mathrm{N}=1588$, joista 550 yksityistä kirjevas- 
taajaa, 310 yksityistä sähköpostivastaajaa, ja 728 kirjevastaajaa 26 koulusta) yhdestä mediapäivästä, torstaista 29. 11. 2001. Aineisto on tallennettu Kansanrunousarkistoon, jossa se on tutkijoiden saatavilla (ks. http://www.finlit.fi/kra/ kra_yleisluettelo.htm\#yksipa). Päiväkirjoista on toimitettu myös teos, johon on otettu mukaan 106 eri-ikäisten kirjoitusta (Suoninen ym. 2003).

(5) Tämän tapaisten kysymysten herääminen on luontaista laadullisten aineistojen tulkinnassa, miksei muunkinlaisessa analyysissa. Erityisesti etnografinen kenttätyö, mutta myös eloisasti kirjoitetut valmiit aineistot saattavat vetää mukaansa, laittaa eläytymään tutkittavan asemaan ja suuntaamaan kysymykset kohti itseä.

(6) Työskennellessäni aikuiskasvatuksen professorina Joensuun yliopistossa 2004-2006 valmistimme uuden opetussuunnitelman, jossa mediakasvatuksella on keskeinen paikka. Tampereen yliopisto, jonne Joensuusta elokuussa 2006 siirryin, on tältä osin avoin kirja, mutta mahdollisuudet ovat olemassa myös aikuiskasvatuksen näkökulman huomioivaan monitieteelliseen mediakasvatuksen tutkimukseen ja opetukseen.

(7) Tässä suhteessa voi muistuttaa uutiskriteereitä koskeneesta empiirisestä tutkimuksesta (Galtung \& Ruge 1965), jossa löydettiin muun muassa läheisyysperiaate (mitä lähempänä jotain tapahtuu, sitä herkemmin siitä kerrotaan), yksinkertaisuusperiaate (kaukainen tapahtuma ei voi olla kovin monimutkainen ylittääkseen uutiskynnyksen), onnettomuusperiaate (mitäjärkyttävämpää, sitä varmemmin siitä uutisoidaan) ja statusperiaate (mitä korkeampi yhteiskunnallinen asema, sitä helpompi saada äänensä mediassa kuuluviin, ellei sitten tee jotain moraalisesti tai muuten kiellettyä) (vrt. Harcupin \& O’Neillin [2001] myöhemmin esittämiin kriteereihin).

\section{Lähteet}

Allman, Paula (2001). Critical Education Against Global Capitalism. Karl Marx and Revolutionary Critical Education. Westport, CT: Bergin \& Garvey.

Bauwens, Michel (2005). The Political Economy of Peer Production. CTheory. www.ctheory.net/articles.aspx?id=499 (23.5.2006)
Boughton, Bob (1997). Does Popular Education Have a Past? In Boughton, B., Brown, T. \& Foley, G. (toim). New Directions in Australian Adult Education. Sydney: University of Technology Sydney (UTS), Centre for Popular Education, 1-27.

Brookfield, Stephen (1996). Postscript: an agenda for research and policy. Teoksessa Tuijnman, Albert (toim.). International Encyclopedia of Adult Education and Training. 2. painos. Oxford: Pergamon, 889-895.

Brookfield, Stephen (2005). The Power of Critical Theory. San Francisco: Jossey-Bass.

Cremin, Lawrence (1975). Public Education and the Education of the Public. Teachers College Record 77 (1), 1-12. http:// www.tcrecord.org, ID Number: 1260 (13. 4. 2006)

Elias, John \& Merriam, Sharan (2005). Philosophical Foundations of Adult Education. Second edition. Malabar: Krieger.

Eskola, Jari \& Suoranta, Juha (1998). Johdatus laadulliseen tutkimukseen. Vastapaino.

Foley, Griffin (2001). Radical Adult Education and Learning. International Journal of Lifelong Education 20 (1-2), 71-88.

Foley, Griffin (2005). Educational Institutions: Supporting Working-Class Learning. Teoksessa Nesbit, Tom (toim.). Class Concerns. Adult Education and Social Class. New Directions for Adult and Continuing Education. San Francisco: Jossey-Bass, 37-44.

Freire, Paulo (1973). Education for Critical Consciousness. New York: Continuum.

Freire, Paulo (1998). The Adult Literacy Process as Cultural Action for Freedom. Harvard Educational Review 68 (4), 480-498. (Julkaistu alunperin samassa lehdessä 1970)

Freire, Paulo (2005). Sorrettujen pedagogiikka. Suom. Joel Kuortti. Vastapaino. (Julkaistu alunperin 1968.)

Freire, Paulo \& Macedo, Donaldo (1987). Literacy: reading the word and the world. Westport \& London: Bergin \& Garvey.

Gadotti, Moacir (1994). Reading Paulo Freire. Albany: SUNY.

Galtung, Johan \& Ruge, Mari Holmboe (1965). The Structure of Foreign News. Journal of Peace Research2 (1), 64-91 
Gauntlett, David \& Hill, Annette (1999). TV Living. Televisio, culture and everyday life. London \& New York: Routledge.

Guy, Talmadge (2006). Adult Education and the Mass Media in the Age of Globalization. Teoksessa Merriam, Sharam, Cortenay, Bradley, Cervero, Ronald (Eds.). Global Issues and Adult Education. Perspectives from Latin America, Africa and the United States. San Francisco: Jossey-Bass, 64-77.

Harcup, Toni \& O'Neill, Deirdre (2001). What Is News? Galtung and Ruge revisited. Journalism Studies 2 (2), 261-280.

Harva, Urpo (1957). Ihminen etsii itseään. Otava.

Harva, Urpo (1964). Ihminen hyvinvointivaltiossa. Kirjayhtymä.

Harva, Urpo (1980). Yleissivistyksen historiasta ja elinikäisestä kasvatuksesta. Teoksessa Huuhka, K. ym. (toim.). Yleissivistys kasvatuksen tavoitteena. Vapaan sivistystyön 23. vuosikirja. Kansanvalistusseura ja Aikuiskasvatuksen Tutkimusseura. WSOY, 9-40.

Heinonen, Ari, Mäkinen, Maarit, Ridell, Seija, Martikainen, Ari, Halttu, Mika \& Sirkkunen, Esa (2000). Locality in the Global Net. The Internet as a Space of Citizen Communication and Local Publicness. Tampereen yliopiston tiedotusopin julkaisuja C 33. http:// tampub.uta.fi/index.php?Aihealue_ld=7 (30.7.2006)

Herkman, Juha (2001). Audiovisuaalinen mediakulttuuri. Vastapaino.

Herkman, Juha (2005). Kaupallisen television ja iltapäivälehtien avoliitto. Vastapaino.

Huttunen, Rauno \& Suoranta, Juha (2006). Critical and Cultural Orientation in Radical Adult Education. Teoksessa Antikainen, A., Harinen, Päivi \& Torres, Carlos Alberto (toim.). In from the Margins. Adult Education, Work, and Civil Society. Rotterdam: Sense Publishers, 27-38.

Holst, John (2002). Social Movements, Civil Society, and Radical Adult Education. Westport, CT: Bergin \& Garvey.

Kellner, Douglas (1998). Mediakulttuuri. Suom. Riitta Oittinen ja muut. Tampere: Vastapaino.

Lehtimäki, Hanna \& Suoranta, Juha (toim. 2006). Kasvattajan brändikirja. Finn-Lectura.
Lewis, Justin, Wahl-Jorgensen, Karin \& Inthorn, Sanna (2004). Images of Citizenship on Television News: constructing a passive public. Journalism Studies 5 (2), 153-164.

Lovett, Tom (1988). Radical Approaches to Adult Education. A Reader. London: Routledge.

Marcuse, Herbert (1969). Yksiulotteinen ihminen. Suom. Markku Lahtela. Weilin+Göös.

Marcuse, Herbert (2006). Aggressiveness in Advanced Industrial Society. Julkaistu alunperin teoksessa Marcuse H. 1968. Negations: Essays in Critical Theory. Boston: Beacon Press. http://www.wbenjamin.org/ marcuse.html (12. 4. 2006)

Marx, Karl \& Engels, Friedrich (2006). Kommunistinen manifesti. (Julkaistu alunperin 1848) http://www.sosialistiliitto.org/nettik/ Amanifes.htm (5.4.2006)

Merriam, Sharam \& Cunningham, Phyllis (toim.) (1989). Handbook of Adult and Continuing Education. San Francisco: JosseyBass.

Moores, Shaun (2000). Media and Everyday Life in Modern Society. Edinburgh University Press.

Nesbit, Tom (toim.) (2005). Class Concerns. Adult Education and Social Class. New Directions for Adult and Continuing Education. San Francisco: Jossey-Bass.

Newman, Michael (2006). Teaching Defiance. Stories and Strategies for Activists Educators. San Francisco: Jossey-Bass.

Seppänen, Janne (2005). Visuaalinen kulttuuri. Vastapaino.

Sihvonen, Jukka (2004). Mediatajun paluu \{pistokkeen päässä\}. Like.

Silverstone, Roger (1999). Television and Everyday Life. London \& New York: Routledge.

Silverstone, Roger (toim.) (2005). Media, Technology and Everyday Life in Europe: from information to communication. Aldershot: Ashgate Publishing.

Sirkkunen, Esa \& Kotilainen, Sirkku (2004). Towards Active Citizenship on the Net. Possibilities of Citizen Oriented Communication: Case Studies from Finland. Tampereen yliopiston Tiedotusopin laitoksen julkaisuja C 
37. http://tampub.uta.fi/

index.php?Aihealue_ld=7 (30.7.2006)

Suoninen, Annikka, Nirkko, Juha \& Kytömäki, Juha (2003). Yksi päivä mediaa. SKS.

Suoranta, Juha (2003). Kasvatus mediakulttuurissa. Vastapaino.

Suoranta, Juha (2005). Radikaali kasvatus. Gaudeamus.

Suoranta, Juha \& Lehtimäki, Hanna (2004). Children in the Information Society. New York: Peter Lang.

Tett, Lyn (2005). Learning, Literacy, and Identity. Teoksessa Nesbit, Tom (toim.). Class Concerns: adult education and social class. New Directions for Adult and Continuing Education 106. San Francisco: Jossey-Bass, 27-36.

Thomas, J. E. (1982). Radical Adult Education. Theory and Practice. Nottingham: University of Nottingham.

Thompson, J. L. (toim.) (1980). Adult Education for a Change. London: Hutchinson.
Youngman, Frank (1986). Adult Education and Socialist Pedagogy. London: Croom Helm.

Volkmer, Ingrid (2006). News in Public Memo$r y$ : an International study of media memories across generations. New York: Peter Lang.

Westwood, Sallie \& Thomas, J.E. (toim.) (1991). Radical Agendas? The Politics of Adult Education. London: NIACE.

Wilson, Arthur \& Hayes, Elisabeth (toim.) (2000). Handbook of Adult and Continuing Education. New Edition. San Francisco: Jossey-Bass.

Žižek, Slavoj (2006a). Nobody has to be vile. London Review of Books. http:// www.lrb.co.uk/v28/n07/zize01_.html (5.4.2006)

Žižek, Slavoj (2006b). The Parallax View. Cambridge, Massachusetts: MIT Press.

Artikkeli saapui toimitukseen 18.4.2006

Se hyväksyttiin julkaistavaksi 15.8.2006. 